\title{
The Relevance of International Financial Reporting Standards for Small and Medium-sized Entities: An Australian Case Study
}

\author{
Gregory Kenneth Laing (Corresponding author) \\ Faculty of Arts \& Business \\ University of the Sunshine Coast \\ Maroochydore DC Qld 4558 Australia \\ Email: glaing@usc.edu.au Telphone: +61 754594675
}

Kenneth Thomas Laing

(Retired)

Received: January 29, 2012 Accepted: February 15, 2012 DOI: 10.5296/ijafr.v2i1.1276

\begin{abstract}
The purpose of this paper is to examine the relevance of imposing a set of accounting standards on Small and Medium-sized entities. This paper involves a multiple case study approach based on an examination from personnel experiences of owning and operating Small and Medium-sized Entities in Australia over a period of 50 years. The key finding from the case studies is that SME's are strongly influenced by the prevailing taxation regulations rather than any form of accounting standard requirements. The cost of meeting the financial reporting requirements is a burden that SME's are ill prepared to bear and such costs are not justified by any claim to being useful for the owners or other possible stakeholders. Further, the issues of comparability and consistency have yet to be shown as providing a benefit to any stakeholder.This paper provides an opportunity for greater debate and research into the financial reporting requirements for SME's.
\end{abstract}

Keywords: Small and Medium-sized Entities; International Financial Reporting Standards; Case Study. 


\section{Introduction}

Government regulation of business activities, which are usually intended to address social or economic problems, are often nothing more than a minor inconvenience to larger businesses. However, from the perspective of small family businesses the very same regulations can be a more serious burden. In Australia the regulatory response to the financial collapse of Health International Holdings (HIH) Insurance Ltd was to introduce the Corporate Law Economic Reform Program Act 2004 (CLERP 9) which made the accounting and auditing standards legally enforceable. This legislative action was undertaken to protect the public interest against corporate failures and closely mirrored similar regulatory reforms in the United Kingdom (UK), the United States of America (USA) and other countries (Clarke et al, 2003). As with most well-intentioned regulatory intervention CLERP 9 there are some consequences.

By enshrining the accounting and auditing standards within the Australian Corporations Act 2001 all registered companies regardless of size became subject to the same regulations. This effectively meant that all registered companies could possibly become subject to the same financial reporting requirements. The merit of treating all companies as the same has long been the subject of research and debate (Morina \& Senkow, 2009; Friedlob \& Plewa, 1992).

The debate in the literature has focused on the production of financial reports to satisfy the external users of the financial information (Williams \& Tower, 1998; Holmes, Kent \& Downey, 1991; Eierle 2005). Underpining the debate is the premise that shareholders and financial institutions require the same level of protection when dealing with Small Medium Enterprise (SME) companies as they do for the larger companies, especially publicly listed companies (Knutson \& Wichmann, 1984; Brailsford \& Ramsay, 1993).

This is by-enlarge a misconception of the relationships that exist between the external parties and the SME companies. Firstly, with regards to shareholders the majority of SME companies are family owned and controlled and the need for legal intervention to assure access to the financial records is misguided and irrelevant. SME companies are more concerned with keeping financial accounting records that satisfy the Australian Tax Act and any other State or Federal Government legislation that may impose on the operating of a particular type of business. For example, Solicitors, Real Estate Agents, Travel Agents, Insurance Agents and Brokers are subject to legislation that imposes the requirement to operate trust accounts. Secondly, the financial institutions are in a stronger position to demand from SME companies whatever financial information they deem necessary before granting a loan.

The result of CLERP9 has been to impose the shadow of the Australian Accounting and Auditing Standards, which are for the most part based on the International Accounting Standards, over SME companies. However, this depends in the first instance upon the application of the Australian Corporations Act 2001 (as amended). The Corporations Act 2001 section 285 sets out the annual financial reporting requirements of registered companies. The preparation of financial reports in accordance with the Australian Accounting Standards by registered companies is only mandatory where the company is deemed to be a 'disclosing 
entity' as per sections $111 \mathrm{AC}$ to $111 \mathrm{AL}$ of the Corporations Act. Basically a disclosing entity is a company which:

- Is listed on the stock exchange;

- Is a company or investment scheme that is raising funds pursuant to the issue of a prospectus and which has at least 100 shareholders;

- Is a company or investment scheme that is offering securities other than debentures as consideration for an acquisition of shares in a target company under a takeover scheme; and

- Companies whose securities are issued under a compromise or scheme of arrangement.

As the above criteria are not common to a small business, even if it was a registered company, an SME would not be classified as a 'disclosing entity'. As such the mandatory application of Accounting Standards would not apply. Under section 292 (2) (a) a small proprietary company does not have to prepare the annual financial report and directors' report unless it is directed to do so in accordance with section 293 or section 294.

This leads to the Statement of Accounting Concepts 1 (SAC 1) 'Definition of the Reporting Entity' which defines general-purpose financial statements (GPFSs) as statements intended to meet the information needs common to users who are unable to command the preparation of reports tailored to their specific needs. GPFSs are to be produced by entities who have users who cannot command the preparation of specific information. The criteria or factors that may be used to indicate that an entity is a 'reporting entity' include:

- Separation of management from those with an economic interest in the entity.

o It is considered that as the spread of ownership and/or the separation of management and ownership increase, so does the likelihood of an entity being a reporting entity.

- Economic or political importance/influence.

$\circ$ It is considered that as the entity's dominance in the market and/or it potential influence on the welfare of external parties increase, so does the likelihood of an entity being a reporting entity.

- Financial characteristics of an entity that may be used in the determination are:

o It is considered that as the amount of sales, value of assets, extent of indebtedness, number of customers and number of employees increase, so does the likelihood of an entity being a reporting entity.

The International Accounting Standards Board (IASB) framework has considered a primary qualitative characteristic of general purpose reports to be 'understandability' of the financial information. Within the IASB framework 'understandability' is held to be reliant upon the likelihood that users will have some business and accounting knowledge. This is a biased 
view because it assumes that the readers of financial reports have some level of proficiency in understanding accounting practices and procedures.

With regards to financial reporting for SME's the IASB issued a discussion paper in June 2004 to commence a project aimed at establishing the appropriate set of International Financial Reporting Standards (IFRS) for SME's. In effect a process of examining the issues of establishing a basis for differential reporting by SME's. It culminated in the issue of a set of guidelines on what has become known as the International Financial Reporting Standards for SME's. The key sequence of events that culminated in the determination of IFRS for SME's are:

- June 2004 Discussion paper published for comment.

- April 2005 Staff questionnaire on SME recognition and measurement issues for comment.

- October 2005 Public round-table meetings on possible recognition and measurement simplifications.

- February 2007 Exposure Draft of IFRS for SMEs

- July 2009Final IFRS for SMEs issued, with effect as at that date.

Interestingly the Australian Accounting Standards Board did not adopt the IFRS for SME's as it had done for the IFRS which relate to larger companies more predominantly listed on the Australian Stock Exchange. They choose instead to retain the concept of the 'reporting entity' as defined in SAC1 and rely upon the professional judgment of the accountants. The professional accounting bodies were opposed to the way in which the IFRS for SME's was structured and basically considered the reporting entity concept espoused in SAC1 to be the preferable option in Australia (Palmer, 2007).

All of the proposed changes come with a cost to meet the financial reporting that would be imposed on SME's. Chilton and Weidenbaum (1982) argued that one of the most serious threats to the continued existence of any SME is the consequences of government regulation. They based their argument on the limited ability of an SME to pass on the increased costs of meeting regulation. This additional work also detracts from the time and efforts that the proprietor of an SME might otherwise allocate to activities such as planning, marketing or managing the business (Peterson, Kozmetsky \& Ridgeway, 1984). One estimate (Donofrio, 1980) was that approximately one quarter of the time of an owner operator of an SME could be spent in meeting the paperwork required by government regulation. Accordingly, this non-productive time is a serious threat to the continued operations of an SME. When government regulation is narrowed down to financial reporting standards the costs to SME's were identified by Friedlob and Plewa (1992) as also involving such things as:

- Increased audit fees,

- Increased bookkeeping costs, and

- Inappropriate management decisions based on information not totally understood. 


\section{MInstitute Mach $^{m}$}

International Journal of Accounting and Financial Reporting ISSN 2162-3082 2012, Vol. 2, No. 1

For the most part SME's do not have shareholders who would be unable to demand information concerning the financial position of the business, nor do they deal with customers or lenders of money that would not be able to exert their demands for financial information. Given the organizational structure of SME's there is nowhere near the need to have the level of regulation regarding the financial reporting standards as applies to large Corporations. Indeed many of the disclosures stipulated in the financial accounting standards are directed to providing disclosure of a nature that more suits the larger publicly-owned corporations (Knutson \& Wichmann, 1984).

\section{Methodology}

This paper employs a multi case study approach derived from actual experiences of owning and operating small and medium-sized entities in Australia. The discussion takes the form of historical reflection using the financial reporting requirements as a form of lens through which the issues are addressed. The discussions are a form of open interview that provides a focus on the issues within a real-life context of having owned and operated small and medium sized business enterprises.

The case study method according to Yin (1989) offers an opportunity to gain rich insights into actual events to generate knowledge and assist in the formulation of theory. The tactics suggested by Yin (1989) were followed to mitigate possible limitations normally associated with interpretation. In particular a multiple case study approach provides validity in terms of the cross validation of the relationship between issues being addressed. Yin (1989, p.41) indicated that this was a form of replication that was inherent within the multiple case study.

\section{Case Studies}

From personal experience gained from establishing and operating various family businesses the authors can attest to the emphasis having been placed on financial accounting systems that follow the prescribed taxation regulations. In contrast the day-to-day management and control of the business was very much dependent upon monitoring cost and production efficiency as the following history indicates.

The first family business, which comprised a husband and wife team, commenced in 1947 with the production of manchester and napery. The main contract was for the supply of the goods to Farmers Department Store in Sydney. By 1949 the business had expanded and there were eight machinists working to meet the growth in demand with the addition of another large customer, Anthony Horderns department store. As a consequence of the increasing network of customers the business branched out into dress-making in 1950. From the start the accountant advising the family was a Mr Scanlon, and perhaps this was fortuitous because he was from the Scanlon family that owned and operated one of the larger and certainly more diverse business firms at the time. Subsequently, he had a very astute awareness of the cost of production and the concept of production efficiency which proved to be beneficial to the continued success and growth of the business. Consequently, the production cost reports and a very rudimentary income report were produced monthly. As for the financial reports, such as the Income Statement and the Balance Sheet, these were produced annually in accordance 


\section{MInstitute Macrothink $^{m}$}

International Journal of Accounting and Financial Reporting ISSN 2162-3082 2012, Vol. 2, No. 1

with the taxation regulations they simply satisfied the need to know just how the business had fared in a particular year for the purpose of taxation. Interestingly the business declined in the 1950's as a result of the Australian Federal government removing Tariffs on imports. This was a precursor of what we to-day would refer to as the global economy or world market.

The next family business was a Real Estate Agency, which started in 1953 at Yagoona on the outskirts of Sydney, and involved an extended family member, that is a cousin. To assist in establishing the business a retired agent was employed and the central focus of the accounting system was about the records pertaining to sales or rentals of properties. Whilst the regulations were not as prescriptive in terms of the trust accounting requirements in force for Real Estate agents to-day there were impelling reasons for maintaining client records. The foremost of which was the determination of any commissions for sales. Here again the production of the financial reports, Income Statement and Balance Sheet, were very much relegated to only being important at the end of year and then they were completed to satisfy the specifications of the taxation legislation. At the time there was very little government regulation and the operation of a trust account was a minimal aspect of the accounting system that fitted more with monitoring the income and commissions receivable.

After a period of working for an Insurance company the next family business was an Insurance Brokerage which commenced operations in 1964. The main accounting concerns were the monitoring of the Accounts Receivables, that is the customers who owed for their insurance premiums, and the Accounts Payables, that is the insurance companies to whom insurance premiums were owed. A similar concept to the one developed in the Real Estate of monitoring receivables and payables for the income particularly commissions. As with the previous businesses the financial reports were merely an annual occurrence and in general were about complying with the tax regulations. In 1975 the introduction of the Insurance Agents \& Brokers Act imposed the requirement for the establishment of a Trust Account and an annual audit of the financial reports which had to be lodged with the Office of the Insurance Commissioner. The main focus of the act was on the relationship between the trust account and the reconciliation of Accounts Receivable to Accounts Payable, so in effect there was no major change in the accounting system for the business these had always been our priority. As for the benefits to the public from the introduction of this legislation, insurance agents and brokers still went into liquidation, in much the same way as FAI and HIH did regardless of the Insurance Act.

\section{Discussion}

Whilst these cases provide some degree of insight into the level of importance a family business may place on the relevance of adhering to financial accounting standards the issue is that should the IFRS for SME's be accepted by the Australian Accounting Standards Board they would be more likely to apply to all SME's. This would mean that the classification as a 'reporting entity' under SAC1 would no longer be relevant regardless of whether the SME was a registered company or merely a business entity. At this juncture it is worth noting that the Australian Securities and Investments Commission (ASIC), who are charged with the oversight of the Corporations Act, do not require the submission of audited annual financial 


\section{Mll Macrothink}

International Journal of Accounting and Financial Reporting ISSN 2162-3082 2012, Vol. 2, No. 1

reports from small proprietary companies (family businesses) merely an undertaking by a Director that the company is not trading whilst insolvent. When faced with the question of determining whether a company is trading whilst insolvent it should be noted that ASIC can make a presumption of insolvency from a contravention of section 286 of the Corporations Act. In effect if the accounting records have not been kept in accordance with the accounting standards then the company is deemed to be insolvent and the Directors of the company are liable and may be prosecuted. More importantly proceedings may be initiated by creditors to place the company in to liquidation.

For the purpose of financial reporting the concept of having special accounting standards which apply only to SME's is dubious. Most SME's do not have the need to produce general purpose financial reports as they only rarely have any dealings with people or organizations that could not demand financial information. Small proprietary companies are frequently not considered to be reporting entities because it is generally assumed that most people who require financial information about the SME will be in a position to specifically demand it. The arguments for not introducing the added burden of regulated financial reporting are therefore: that a disproportionate amount of cost will have to be borne by the SME owners; the users of financial reports of SME's are different from those of the large and publicly owned corporations; potential users of SME's financial information generally possess a degree of authority and can obtain financial information they require. Turning to the issue of usefulness to users: SME's are excluded from offering shares to the general public and this is therefore not a relevant matter for concern; banks and financial institutions have their own specific financial information requirements that do not relate to the accounting standards; suppliers of goods or services have their own requirements and impose restrictions according to the industry in which the SME is operating so this also is not a relevant concern.

In other countries where accounting standards have been imposed on SME companies increases in the cost of compliance with accounting and auditing services for SME companies has been reported (Wise, 2005; Morina \& Senkow, 2009). The problem is that IFRS for SME's are generally not pertinent to the management or control of a family business, because they are intended to cover the possible needs of a broad group of users of financial information which extend beyond those of the family business. Most family businesses are concerned with running their business efficiently and effectively the main concern is to work within the confines of the prevailing taxation system. That is, income and expenses calculated in accordance with accounting standards may provide a profit figure, however, the taxable income after deductions is the major concern for SME companies when it comes to determining their annual financial reports.

\section{References}

Brailsford, T. \& Ramsay, A. (1993). Issues in the Australian differential reporting debate, Journal of International Accounting Auditing \& Taxation, 2(1): 43-58.

Chilton, K. \& Weidenbaum, M. (1982). Government Regulation: The Small Business Burden, Journal of Small Business Management, 20(1): 4-10. 


\section{Macrothink}

International Journal of Accounting and Financial Reporting

ISSN 2162-3082

Clarke, F., Dean, G. \& Oliver, K. (2003). Corporate Collapse - Accounting, Regulatory and Ethical Failure, $2^{\text {nd }}$ Edn., Cambridge University Press: UK.

Donofrio, H.C. (1980). On Comprehending and Managing Excessive Governmental Regulation of Small Business, American Journal of Small Business, (Spring), 5-10.

Eierle, B. (2005). Differential reporting in Germany - A historical analysis, Accounting, Business \& Financial History, 15(3): 279-315.

Friedlob, G. \& Pleewa, F. (1992). Cost Effective Financial reporting for Small Business, Journal of Small Business Management, 30(1): 89-94.

Holmes, S., Kent, P. \& Downey, G. (1991). The Australian Differential Reporting Debate: A Survey of Practitioners, Accounting and Business Research, 21(82): 125-132.

Knutson, D. \& Wichmann, H. (1984). GAAP Disclosures: Problem for Small Business?, Journal of Small Business Management, 22(1):38-46.

Morina, D. \& Senkow, D. (2009). Financial reporting for Private Companies: The Canadian Experience, Accounting Perspectives, 8(1): 43-44.

Palmer, B. (2007). Letter to the Australian Accounting Standards Board, The Institute of Chartered Accountants in Australia, Sydney

Peterson, R., Kozmetsky, G. \& Ridgway, N. (1984). Opinions about Government Regulation of Small Business, Journal of Small Business Management, 22(1): 56-62.

Williams, S. \& Tower, G. (1998). Differential reporting in Singapore and Australia: A small business managers' perspective, The International Journal of Accounting, 33(2): 263-269.

Wise, V. (2005). SME Differential Reporting Survey, Chartered Accountants Journal of New Zealand, 84(2): 39.

Yin, R.K. (1989), Case Study Research Design and Methods, Sage Publications: Beverly Hills. 